\title{
Atmospheric Radiation Measurement (ARM) Aerosol Observing Systems (AOS) for Surface-Based In Situ Atmospheric Aerosol and Trace Gas Measurements
}

\author{
Janek Uin, ${ }^{a}$ Allison C. Aiken, ${ }^{\mathrm{b}}$ Manvendra K. Dubey, ${ }^{\mathrm{b}}$ Chongai Kuang, ${ }^{\mathrm{a}}$ Mikhail Pekour, ${ }^{\mathrm{c}}$

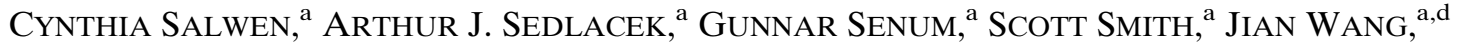 \\ THOMAS B. WATSON, ${ }^{\mathrm{a}}$ AND STEPHEN R. SPRINGSTON ${ }^{\mathrm{a}}$ \\ ${ }^{a}$ Environmental and Climate Sciences Department, Brookhaven National Laboratory, Upton, New York \\ ${ }^{\mathrm{b}}$ Earth and Environmental Sciences Division, Los Alamos National Laboratory, Los Alamos, New Mexico \\ ${ }^{\mathrm{c}}$ Atmospheric Sciences and Global Change Division, Pacific Northwest National Laboratory, Richland, Washington \\ ${ }^{\mathrm{d}}$ Center for Aerosol Science and Engineering, Department of Energy, Environmental and Chemical Engineering, \\ Washington University in St. Louis, Saint Louis, Missouri
}

(Manuscript received 3 May 2019, in final form 5 September 2019)

\begin{abstract}
Aerosols alter Earth's radiative budget both directly and indirectly through interaction with clouds. Continuous observations are required to reduce the uncertainties in climate models associated with atmospheric processing and the interactions between aerosols and clouds. Field observations of aerosols are a central component of the Atmospheric Radiation Measurement (ARM) Facility's global measurements. The ARM mission goal is to "provide the climate research community with strategically located in situ and remote sensing observatories designed to improve the understanding and representation, in climate and earth system models, of clouds and aerosols as well as their interactions and coupling with the Earth's surface." Since 1996, ARM has met this goal by operating Aerosol Observing Systems (AOS) for in situ measurement of aerosols. Currently the five ARM AOSs are the most comprehensive field deployable aerosol systems in the United States. The AOS suite includes seven measurement classes: number concentration, size distribution, chemical composition, radiative and optical properties, hygroscopicity, trace gases, and supporting meteorological conditions. AOSs are designed as standardized measurement platforms to enable intercomparison across the ARM Facility for regional process studies within a global context. The instrumentation and measurement capabilities of the ARM AOSs, along with a history of their design and field deployments are presented here.
\end{abstract}

\section{Introduction}

\section{a. Inception of ARM}

Aerosols are ubiquitous in Earth's atmosphere and are directly emitted from natural and anthropogenic sources as well as formed in the atmosphere. They alter Earth's radiative budget directly by absorbing and scattering light and indirectly by altering cloud properties and processes such as formation, lifetime, and albedo. To achieve radiative closure at Earth's surface, knowledge of local aerosol loading and optical properties are required. Because of their high variability (temporally, geographically, and in the vertical profile) and with their numerous direct and indirect impacts to the atmosphere, aerosols represent one of the largest uncertainties in global climate models

Corresponding author: Janek Uin, juin@bnl.gov
(Penner et al. 1992; Charlson et al. 1992; IPCC 2014; Myhre et al. 2009). Continuous multiyear measurements that span the entire range of atmospheric conditions are required to address these uncertainties.

In 1990, the U.S. Department of Energy (DOE; the expansions of acronyms used in this paper are repeated in the appendix for easy reference) started ARM to reduce the uncertainty in climate models for the purpose of improving climate change predictions by collecting observations over a range of atmospheric conditions in climatically important regions of the world (Turner and Ellingson 2016). Measurement sites were established with a critical suite of measurements, driven by a science team that could competitively propose additional measurements and field campaigns. Data collected from the ARM sites were considered to be a research community resource and freely shared across government agencies, universities, private companies, and international institutions. ARM was designed to serve 
the broad atmospheric research community and was designated as a scientific user facility by the U.S. DOE Office of Science, Office of Biological and Environmental Research in 2004.

\section{b. Beginning of ARM aerosol measurements}

Aerosol measurements have been a part of the ARM Facility since 1996 (Mather and Voyles 2013; Stokes and Schwartz 1994; Sisterson et al. 2016; McComiskey and Ferrare 2016; Sheridan et al. 2001), starting with the original Aerosol Observing System (AOS) built by DOE Environmental Measurements Laboratory (EML) (Leifer et al. 1994) and operated by National Oceanic and Atmospheric Administration (NOAA) in collaboration with DOE during the long-term deployment at the Southern Great Plains (SGP) site in Oklahoma. The measurements initially focused on aerosol microphysical and optical properties observed near the surface. Six instruments were included in the original design: a single- and three-wavelength nephelometer, an optical particle counter (OPC), a condensation particle counter (CPC), a Particle Soot Absorption Photometer, and an ozone monitor. The instruments were housed in an exclusive, self-contained shelter with an intake stack that sampled at $10 \mathrm{~m}$ above ground level (Sheridan et al. 2001). The system design provided space for future expansion of instruments. A common manifold supplied all instruments with the same sample air, and an impactor with a $10-\mu \mathrm{m}$ cutoff size limited the aerosol size sampled by a subset of instruments.

In 1997, a switched impactor setup was installed to sample at two size cuts: $<1$ and $<10 \mu \mathrm{m}$. To maintain a reference state comparable to similar measurements made at locations with different ambient conditions, the sample air was slightly heated providing measurements at low relative humidity $(<40 \%)$, while limiting the evaporation of volatile species. In addition, a humidigraph system (Carrico et al. 1998) was installed to measure the change in aerosol optical scattering as a function of water uptake. The SGP site hosted the first Aerosol Intensive Operational Period (IOP) in May 2003, comparing surface, airborne and remote sensing measurements (Ferrare et al. 2006).

A second AOS, based on the original EML design, was built in 2004 in collaboration by NOAA, Pacific Northwest National Laboratory, and Los Alamos National Laboratory. A smaller, 20-ft $(6.1 \mathrm{~m})$ shipping container was used for portability since it was designed to be deployed anywhere in the world as part of the first ARM Mobile Facility (AMF1) (Miller et al. 2016).

\section{c. New-generation BNL-design AOSs}

From 2009 through 2016 ARM expanded its capability with the addition of five new-generation AOSs (two replacing the original EML-NOAA units) built at Brookhaven National Laboratory (BNL) (Mather and Voyles 2013). As a result, there are now two AOSs at fixed-location observatories [at the SGP site in Oklahoma and the East North Atlantic (ENA) site in the Azores, Portugal] and one AOS for each of the three AMFs in ARM. Among these, the AMF2 AOS was built specifically for ship deployments and AMF3 AOS was designed for a longer cold weather deployment at Oliktok, Alaska (OLI). A mobile Aerosol Observing System (MAOS) was also built, containing additional specialized aerosol and trace gas instruments meant to be deployed alongside any of the other AOSs as needed. It was initially named MAOS C and deployed together with AMF1 AOS (then named MAOS A) (Table 1). After the AMF1 reconfiguration in 2018, the MAOS C structure was separated from AMF1 and is on a loan outside of ARM with most of its instrument suite removed.

The new-generation BNL design, following upon the original SGP AOS sampling configuration and expanding the previous measurement capabilities, is now standardized across the ARM Facility for measurements, system configuration and operation. There were some changes from the original EML designed AOSs-the stack is no longer heated, and the switching impactors could not be duplicated so commercial units were bought with the same cutoff parameters. The newgeneration ARM AOSs also extend capabilities beyond the previous generation, by having more classes of aerosol measurements:

- aerosol number concentration (also in the original design),

- hygroscopicity and propensity for cloud formation (also in the original design),

- aerosol radiative properties (also in the original design),

- aerosol size distribution,

- aerosol composition,

- gaseous precursors and other trace gases, and

- supporting meteorological state measurements at the point of sampling.

Having multiple identically operating units with a broad array of instrumentation and equipped for operation under severe environmental conditions is a distinguishing feature of these new-generation AOSs. Other shared features include the following:

- Identical sampling inlets operated under common conditions (flow rates, drying and size cuts) allowing direct comparison of measurements across the different sites within the facility. Although the sample inlet 
TABLE 1. History of AOSs within ARM. Permanent AOS designations are given in parentheses.

\begin{tabular}{|c|c|c|c|c|c|}
\hline Year & AMF1 (AOS01) & AMF2 (AOS02) & AMF3 (AOS03) & ENA (AOS06) & SGP (AOS07) \\
\hline 2010 & & First deployed & & & \\
\hline 2011 & & & & $\begin{array}{l}\text { First deployed as } \\
\text { TWP-Darwin }\end{array}$ & \\
\hline 2012 & $\begin{array}{l}\text { First deployed as MAOS A } \\
\text { with MAOS C }\end{array}$ & & & & \\
\hline 2013 & & & & $\begin{array}{l}\text { Renamed as ENA and } \\
\text { redeployed to Azores }\end{array}$ & \\
\hline 2016 & & & $\begin{array}{l}\text { First deployed to SGP, } \\
\text { redeployed to OLI }\end{array}$ & & First deployed \\
\hline 2018 & $\begin{array}{l}\text { Reconfigured as } \\
\text { MAOS A } \rightarrow \text { AMF1 } \\
\text { MAOS C } \rightarrow \text { MAOS } \\
\text { deployed separately }\end{array}$ & & & & \\
\hline
\end{tabular}

was redesigned for robustness and ease of assembly, the flow regimes, flow distributor and tubing dimensions from the earlier EML design were retained.

- The standard shipping container structure and exterior components are robust and provide a temperaturecontrolled indoor laboratory setting.

- Instruments are installed in shock-mounted racks allowing the entire AOS to be shipped with instruments in place, wired and plumbed. This decreases the setup time on site and reduces problems arising from repeated installations.

Although the AOSs are intended to provide functionally identical measurements there are some differences (see instrument complement for each AOS in Table 3). There are also minor structural differences-the AMF2 AOS has additional weatherproofing for marine deployments and the later AMF3 and SGP units are larger with an additional adjacent shipping container for entry and mechanical systems.

The new-generation ARM AOSs are currently the most comprehensive field deployable aerosol systems in the United States (McComiskey and Sisterson 2018). By being included within ARM Facilities, the AOSs provide verification for current and future remote sensing techniques as well as satellite overflights. Complementary aerosol measurements are also fielded aboard the ARM Airborne Facility (AAF). The AAF provides vertical and spatial information and can be deployed independently or in support of ground measurements (Schmid et al. 2016).

\section{d. AOS deployments, operations, and mentorship}

The ARM AOSs are deployed within the United States and internationally at ground sites and aboard ships with flexibility to meet campaign-specific science goals as defined by accepted campaign proposals from the scientific community (ARM 2016). AOS deployments at fixed sites are operated continuously (SGP since 1996 and ENA since 2013). The other three AOSs are usually collocated with their associated AMF, but have been operated by themselves on occasion. Figure 1 details the history of deployments of the new-generation BNLdesign AOSs. The ARM website (www.arm.gov) lists the scientific drivers for each of the fixed sites and individual field campaigns/IOPs.

AOS deployments are managed by the AMF operator (Cress et al. 2016), who supplies the logistics involved with staging, transportation, site preparation and routine on-site operations. Foreign deployments include a domestic staging and beta testing of the system in final configuration. Beta testing also allows ARM data services to check the end-to-end data flow to the archive.

Individual AOS instruments are operated under the direction of instrument mentors. Instrument mentors are experts of their respective instruments who provide the procurement specifications, perform or oversee calibrations and maintenance, work with the ARM Data Quality Office to automate (where possible) data quality assurance/quality control (QA/QC), develop documentation for and train site operators, and are the ultimate authority for instrument data quality (Peppler et al. 2016). The AOS instrument mentors review deployment details and, if necessary, modify the written protocols for instrument operation.

Once a field site is set up, instrument mentors typically travel to the site for final integration, calibration and instrument verification. A one- to two-week period of data validation prior to the official start date allows time for data inspection and addressing unforeseen circumstances.

During the campaign, on-site operators fill in daily checklists with mentor-defined criteria for normal instrument response. Proper instrument operation is continually verified through data review by operators, mentors, the ARM Data Quality Office who have 


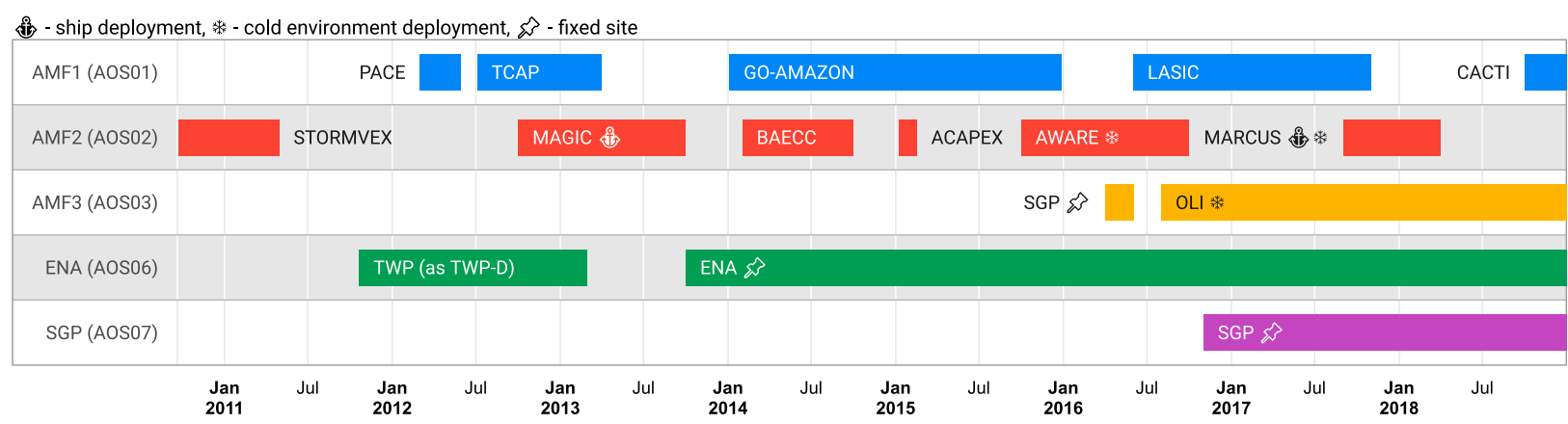

FIG. 1. AOS deployments with campaign/site names until the end of 2018. Note that, prior to the 2018 reconfiguration, AMF1 AOS was named MAOS A and was deployed together with MAOS C (now MAOS). AOS designations are given in parentheses.

automated and manual review processes, or the principal investigator (PI) for the specific campaign who have nearly real-time access to processed data.

\section{System configuration and operation}

\section{a. Instrument container}

The physical structure of an AOS is an International Organization for Standardization (ISO)-standard $8 \mathrm{ft}$ $(2.4 \mathrm{~m})$ width $\times 8.5 \mathrm{ft}(2.6 \mathrm{~m})$ height $\times 20 \mathrm{ft}(6.1 \mathrm{~m})$ shipping container (Fig. 2). The walls, ceiling, and floors of the container are insulated using polyurethane spray foam. The interior walls, floor, and ceiling are lined with plywood for durability and have integrated hard mounts for equipment. Access to the container is through a door on one end of the container that may open directly to the outside environment or through an additional entryway container (at SGP and OLI). The inside of the container is climate-controlled by air conditioning units or heaters, depending on the environmental conditions.

There are three to five instrument racks in each AOS, mounted side by side. The racks are mounted on cable isolators to mitigate vibration and shock during shipping. All instruments, computers, power distributors and networking equipment are mounted in these racks, both during operation and shipping (Fig. 3).

Pumps providing the instrument flows are housed in a customized stainless steel enclosure installed either at the back end of the shipping container or in the entryway container if one is deployed along with the AOS. The pump enclosure has connections for air flows, electrical power and temperature sensors installed inside the box. Another stainless steel enclosure, mounted next to the pump enclosure, houses the dry air supply system. Dry air is supplied by a Puregas P4200 series heatless regenerative air dryer.

The conditions in the AOS are monitored using lowcost commercial voltage, temperature, $\mathrm{RH}$ and pressure sensors installed throughout the container and networked into the AOS data system. The pump enclosure has an additional cabinet temperature sensor as well as temperature sensors on all the pumps in the cabinet. The extensive monitoring allows rapid identification of failing systems, and the data record is useful for data quality assurance.

Power to all the instruments and the infrastructure is provided through networked power distribution units

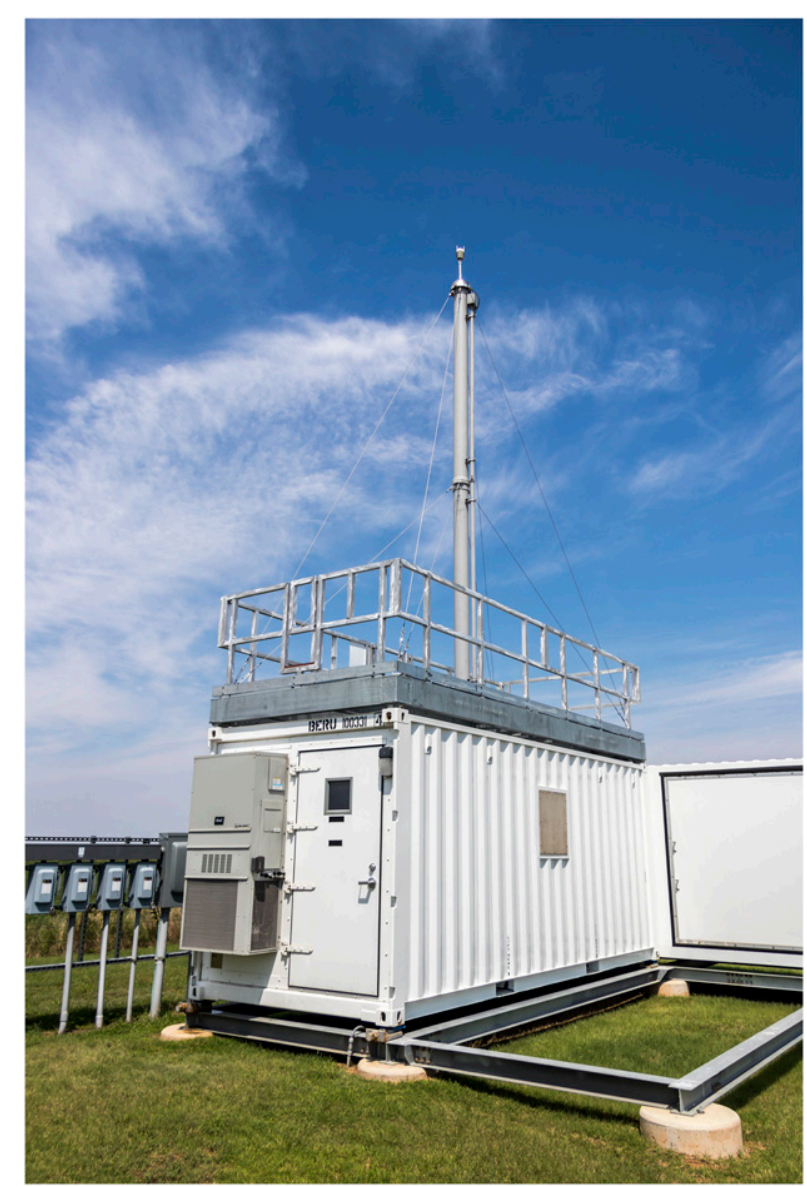

FIG. 2. Outside view of the SGP AOS. Part of the separate entryway container is also visible on the right. 


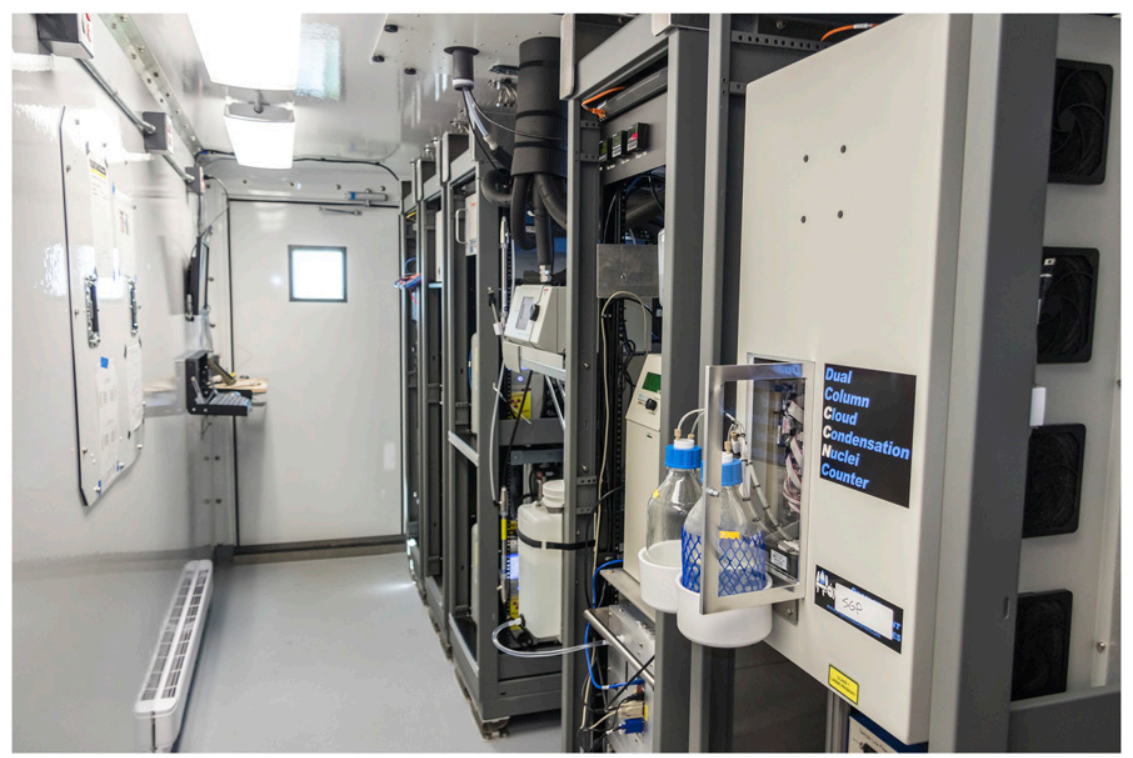

FIG. 3. Inside view of the SGP AOS. The instrument racks can be seen on the right, with the insulated flow distributor visible in the upper center and the operator station in the background on the left.

(PDUs) that allow the power to be remotely controlled and monitored. Sensitive instruments and pumps are further connected to uninterruptible power supplies to provide extra time for a graceful shutdown in case of power failure and to smooth out power fluctuations from generators. Typically, $60 \mathrm{~Hz} / 110 \mathrm{~V}$ is used throughout the AOS, however, for international or shipborne deployments, $50 \mathrm{~Hz}$ can be used, as instruments and the general infrastructure in the AOS are designed to handle different power standards.

\section{b. Sampling system}

The AOS inlet design was based on the earlier EML design (Leifer et al. 1994). The inlet is designed to representatively sample without discrimination due to size or composition. The inlet samples at nominally $10 \mathrm{~m}$ above ground level (except for shipboard deployments) and is composed of two $3-\mathrm{m}$ sections of $20-\mathrm{cm}$ diameter aluminum pipe modified for mounting vertically using guy wires for stability. The aluminum pipe is powder coated gray to prevent corrosion and minimize radiative heating. For ship-based deployments, the inlet is configured to use only a single $3-\mathrm{m}$ section. The inlet is covered by a stainless steel rain shield with a meteorological station mounted on top, providing measurements of the atmospheric conditions at the point of sampling. Installed around the edge of the rain cover are a temperature sensor and a heater. The heater, set to keep the inlet temperature above $5^{\circ} \mathrm{C}$, prevents the buildup of ice around the edge of the inlet in cold environments.

The total flow rate of the stack is controlled at $1000 \mathrm{~L} \mathrm{~min}^{-1}$, of which $150 \mathrm{Lmin}^{-1}$ is extracted under turbulent conditions and drawn through an internal tube to a flow distributor within the container where it is split into five $30 \mathrm{~L} \mathrm{~min}^{-1}$ sample lines (Fig. 4) (Sheridan et al. 2001). The flow distributor and sample lines to the instruments are insulated to prevent water condensation in the lines. Each of the five $30 \mathrm{~L} \mathrm{~min}^{-1}$ sample flows is maintained by a combination of a bypass flow pulled by a vacuum source and the inlet flows of the instruments on that sample line. The bypass flows are measured by rotameters and set manually by adjusting corresponding valves. The relative humidity and temperature of the sample are measured by sensors on one of the sample lines. The inlet has been empirically characterized for particle loss between the particle sizes of $10 \mathrm{~nm}$ and $1 \mu \mathrm{m}$ (Bullard et al. 2017). Trace gas measurements do not use the main stack and sample through a separate $1 / 2$-in. $(1 \mathrm{in} .=2.54 \mathrm{~cm})$ perfluoroalkoxy $(\mathrm{PFA})$ tube running in parallel with the stack.

One of the five inlet lines leads to an impactor setup consisting of two impactors with nominal cut points of 1 and $10 \mu \mathrm{m}$ and an automatic valve that periodically switches the sample flow between them. The position of the impactor valve is recorded by reading the state of mechanical switches installed on the valve. Pressure sensors in the instruments downstream of the impactor 


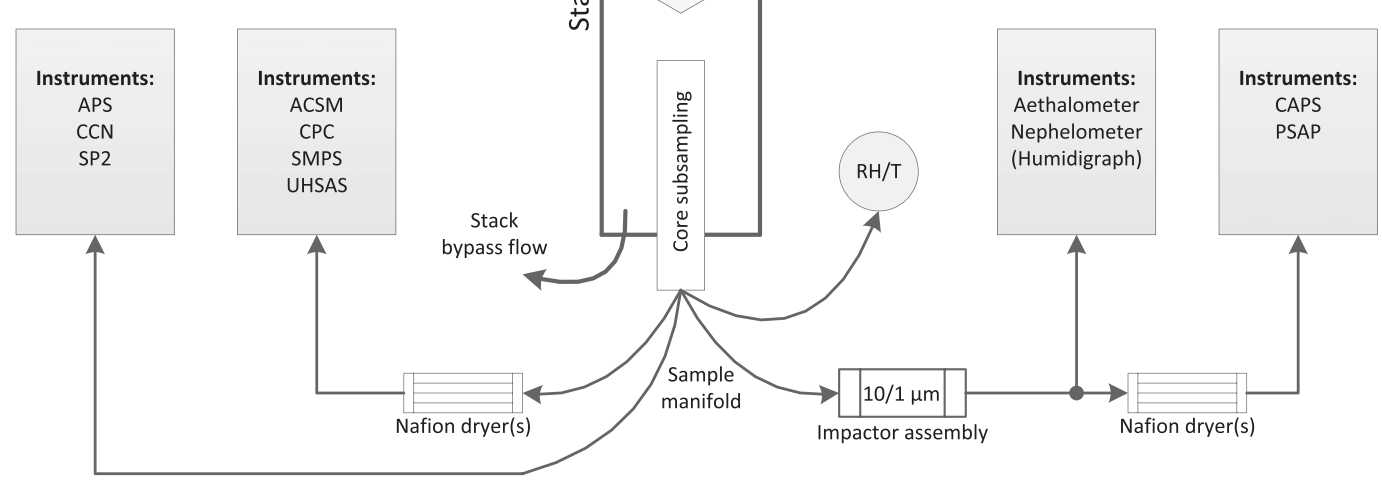

FIG. 4. Schematic diagram of the general setup of the AOS sample flow distribution system. Instrument inlet bypass flows, dried or compressed air lines, and vacuum lines have been omitted for clarity. Instruments on similar but physically separate sample lines have been drawn together. Exact details may vary slightly among individual AOSs depending on the instrument complement. Trace gas measurements do not use the main stack and have a separate inlet, parallel to the main stack.

measure the change in the sample pressure as the impactor valve switches between the two impactors. The pressure difference is used to assess the cleanliness of the impactors, detect leaks on the impactor sample line and provide a confirmation of the position of the impactor valve. For historical reasons, the total sample flow through the impactors has not been dried, however, based on user input from the aerosol community, this procedure is being changed.

Certain instrument sample flows are individually dried using Nafion dryers (see the measurements section below for specific instruments). Purge flows for the Nafion dryers are provided by a vacuum source pulling cabin air through critical orifices installed on the individual dryers. Typically, separate dryers are used with each instrument.

Instruments that size on the basis of particle electrical mobility, require the aerosol sample to be electrically charged to a known charge distribution. During most deployments, this is achieved using sealed radioactive ${ }^{85} \mathrm{Kr}$ or ${ }^{210} \mathrm{Po}$ sources. For some locations, where shipping and receiving sealed radioactive sources is restricted by local regulations (e.g., ENA site), soft $\mathrm{X}$-ray sources are used instead (Tigges et al. 2015). Both types of sources are replaced or refurbished within their respective lifetimes based on the half-life of the radioactive substance or the operational lifetime specified by the manufacturer.

There are provisions in the AOSs for accommodating ARM-approved guest instrumentation, and ARM works with guest PIs to install and operate instrumentation. Guest instruments are plumbed into the sample distribution system based on the needs of the specific instrument, while making sure that their placement doesn't interfere with the existing measurements. The flow rate in the modified sample line is adjusted to compensate for the additional instrumentation.

\section{c. Instrument control and data acquisition}

All standalone and instrument computers in the AOS are connected to an internal network. For security reasons, the AOS network is partitioned into several subnetworks with limited access, so that guest computers and computers with legacy software do not have direct access to the rest of the network, while still being remotely accessible by authorized users. The AOS network is connected to the wider "site data system" (SDS) at each location, which handles data collection from instrument computers and is also used to synchronize the internal clocks of all instrument and computers. UTC is used as the standard in all AOS computers and ARM data products regardless of the deployment time zone.

The computers in the AOS are operated from a single workstation using a keyboard, video and mouse (KVM) switch that connects the workstation to the individual computers. Guest instruments and instruments that lack external video connections are operated directly using their individual user interfaces. All computers in the AOS are also accessible remotely from inside the sitewide network or from outside the site via a secure "virtual private network" (VPN) tunnel maintained by ARM. Remote desktop software is used to interact with computers, transfer files and communicate with locally logged-in users.

Each AOS includes a master computer for monitoring and controlling the AOS. Custom software with a 
graphical user interface running on the master computer is used to control the power to all instruments and pumps. The software also controls the AOS impactor valve and records the ambient conditions in the AOS (temperature, $\mathrm{RH}$, pressure, line voltage), utilizing a collection of sensors installed throughout the AOS.

Instruments in the AOS are controlled either by internal or external data acquisition and control computers that interface with the instruments over serial, Ethernet or USB connections. Currently, the external physical computers are being phased out in favor of virtual machines that run on each site's central data server and connect to individual instruments using networked serial servers installed in the AOS. This allows centralized storage, system backup and transfer of instrument computer setups to new hardware.

Instrument data are collected in different ways depending on the interface options of each instrument. Instruments with internal computers save the raw data on an internal disk in text files, which are then processed using custom LabVIEW programs ["virtual instruments" (VIs)] that rename the files and insert comprehensive metadata such as the instrument name, serial number, sample collection date/time and sampling mode. The files are then automatically collected by the SDS. The SDS copies the files to the site's central file server and then forwards them to the ARM Data Management Center. The original files are left on the instrument computer for redundant storage. Data acquisition from instruments without an internal computer is performed by another set of custom VIs running on an external computer (or a virtual machine) that capture the data directly from the instruments and save it as text files in designated locations where they can be collected by the SDS. These custom VIs also include a user interface that displays real-time data and allows sending control commands to the instrument.

\section{Measurements}

The AOS aerosol and trace-gas instrument suite is based on the original recommendation by the ARM Aerosol Working Group (McComiskey and Ferrare 2016) and covers several different measurement classes as listed in section 1c above. The status of instruments (where installed, specific models deployed) is presented here as it was at the end of 2018 and is summarized in Tables 2 and 3. General instrument capabilities or typical operating parameters (e.g., measurement range or time resolution) are listed below for each instrument. Actual operating parameters may vary between deployments based on user input or as necessitated by ambient conditions and are recorded in the data files.

\section{a. Number concentration and size distribution}

\section{1) APS}

The Aerodynamic Particle Sizer (APS) (TSI, Inc.) measures the size distribution of aerosol particles in the $0.37-20-\mu \mathrm{m}$ range (Peters and Leith 2003). The instrument utilizes particle inertia by measuring particle velocity in an accelerating airflow and relating that to particle aerodynamic equivalent size. Particle velocity is measured by illuminating the particles by two lasers separated in space and measuring the time between pulses of light scattered by the illuminated particles. Additionally, the amplitude of the captured light pulses is used to get a secondary measurement of the particle size. The instrument has 52 size bins in total and a time resolution down to $0.1 \mathrm{~s}$. The APS is installed at AMF1 and SGP.

\section{2) $\mathrm{CPC}$}

The Condensation Particle Counter (TSI, Inc.) measures the number concentration of aerosol particles [Stolzenburg and McMurry 1991; Hermann et al. 2007; Kuang 2016a (ARM instrument handbook)]. The sampled aerosol is first mixed with a supersaturated vapor of a working fluid (in this case, butanol) and then cooled to allow the aerosol particles to grow through condensation of the working fluid. Grown particles are then optically counted by illuminating them with a laser and registering the pulses of scattered light. The sample flow for the CPC is dried using a Nafion dryer.

Two different CPC models are deployed-the TSI model 3772 CPC and the TSI model 3776 ultrafine CPC with particle size lower detection limits at around 10 and $2.5 \mathrm{~nm}$, respectively. The CPC is installed at AMF1, AMF2 (3772 only), AMF3, ENA (3772 only), and SGP.

\section{3) SMPS}

The Scanning Mobility Particle Sizer (SMPS) (TSI, Inc.) measures the size distribution of aerosol particles [Wang and Flagan 1990; Kuang 2016b (ARM instrument handbook)]. The instrument works by giving sampled particles a known electrical charge and then using a differential mobility analyzer (DMA) (Knutson and Whitby 1975; Liu and Pui 1974) to classify the charged particles by their electrical mobility. Particle size is then derived from measured electrical mobility and number concentrations of classified particles in narrow size bins are measured by a CPC to yield a size distribution (Wang and Flagan 1990).

The SMPS is deployed in two configurations using different DMA columns and CPCs to cover different particle size ranges. The nano-SMPS with a nano-DMA and model 3776 ultrafine CPC is used for measurements 


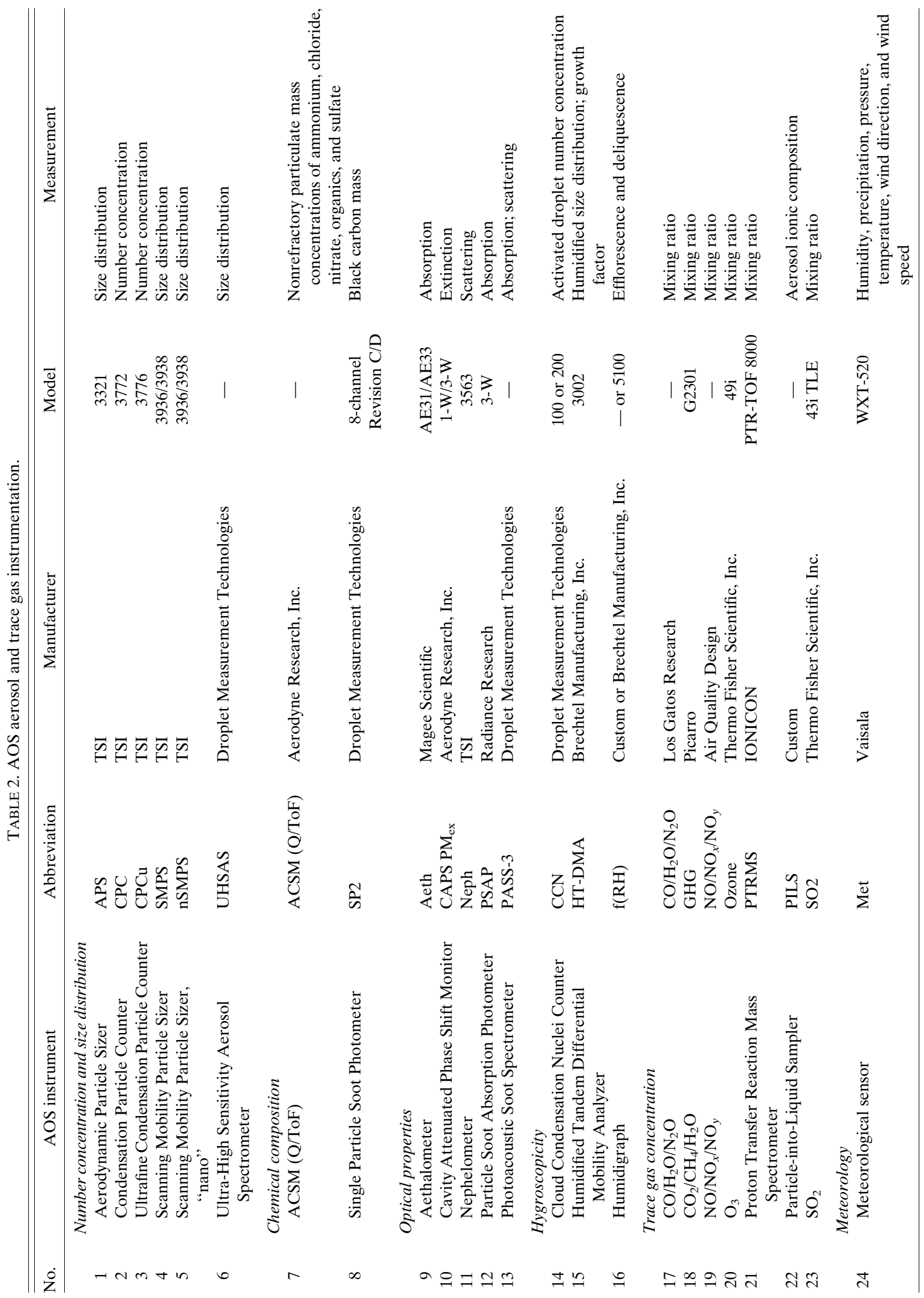


TABLE 3. AOS instrument list by Aerosol Measurement Facility. MAOS (formerly MAOS C) is presented in the state it was before the 2018 reconfiguration. Instruments removed after 2018 reconfiguration are marked with an "o" symbol.

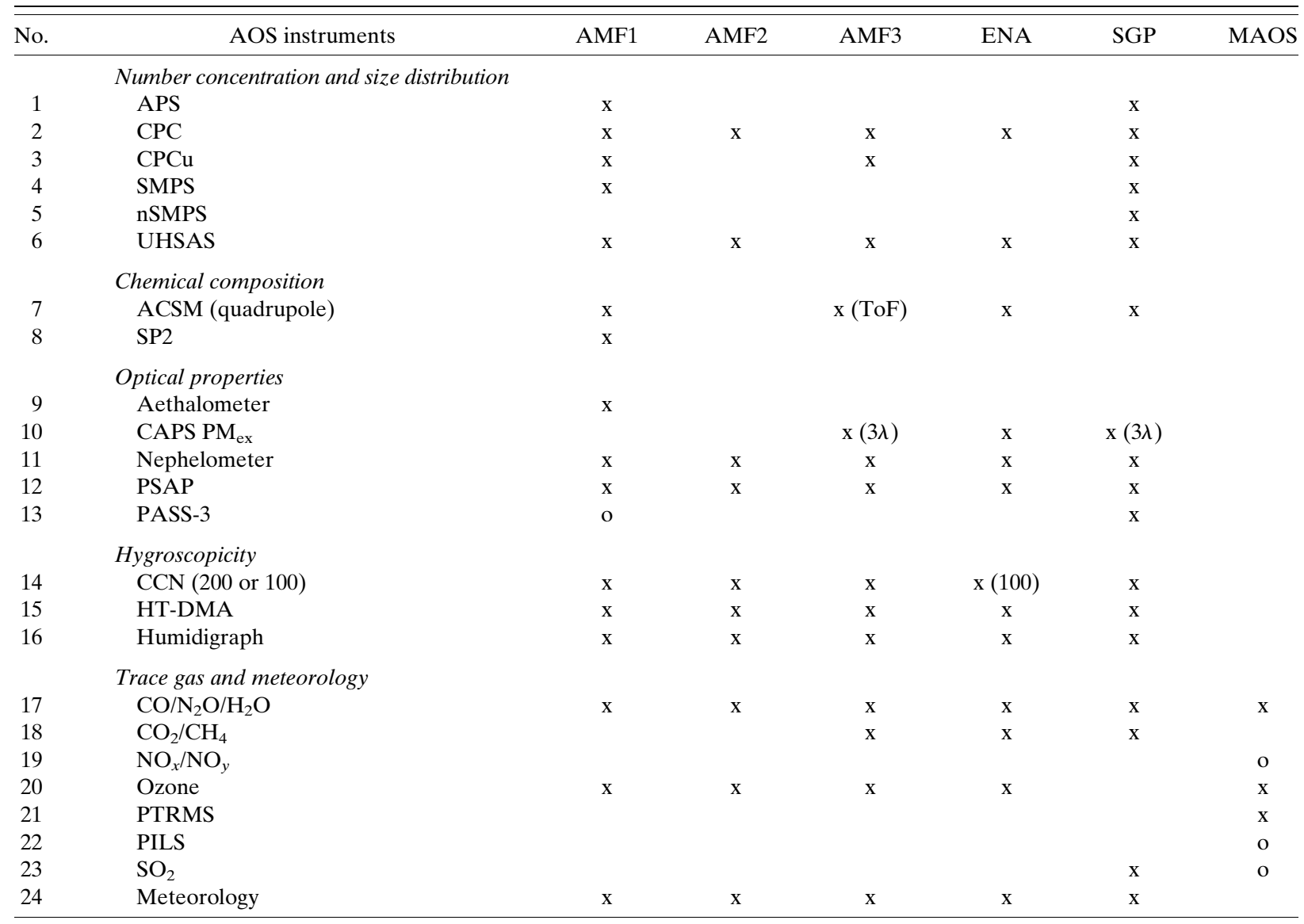

in the particle size range from 2 to $60 \mathrm{~nm}$, and the SMPS with a long DMA and model 3772 CPC in the particle size range from 11 to $460 \mathrm{~nm}$. Each measurement cycle over the complete size range takes $5 \mathrm{~min}$. SMPS sample flow is dried using a Nafion dryer. The SMPS is installed at AMF1 (SMPS) and SGP (SMPS and nano-SMPS).

\section{4) UHSAS}

The Ultra-High Sensitivity Aerosol Spectrometer (UHSAS) (Droplet Measurement Technologies, Inc.) measures the size distribution of aerosol particles in the 60-1000-nm range [Cai et al. 2008; Uin 2016a (ARM instrument handbook)]. The instrument works by illuminating the particles with a 1054-nm wavelength laser and measuring the amount of light scattered each time a particle passes through the laser beam. The amplitude and number of pulses of scattered light are used to determine the particle size and their count. The instrument has 100 size bins and a time resolution down to $1 \mathrm{~s}$. The UHSAS is typically deployed together with one of the CPCs or SMPSs, which provide the transport flow for the UHSAS sample. The sample flow for the UHSAS is dried using a Nafion dryer. The UHSAS is installed at AMF1, AMF2, AMF3, ENA, and SGP.

\section{b. Optical properties}

\section{1) Aethalometer}

The Aethalometer (Aeth) (Magee Scientific) measures light attenuation at seven wavelengths $(370,470$, $520,590,660,880$, and $950 \mathrm{~nm}$ ) through a filter on which aerosol is continuously collected [Rosen et al. 1980; Hansen et al. 1984; Arnott et al. 2005; Drinovec et al. 2015; Sedlacek 2016a (ARM instrument handbook)]. As material is collected on the filter, the attenuation of light by aerosol particles is calculated from the rate of total attenuation change over time. The instrument corrects for the light scattering properties of the filter along with temporal changes in optical source output by simultaneously measuring light attenuation through a reference spot. Aethalometer uses a spool of quartz fiber filter that is advanced automatically.

Black carbon mass concentrations $\left(\mu \mathrm{g} \mathrm{m}^{-3}\right)$ are reported at each wavelength using the aethalometer-specific 
conversion factors specified in the data files to convert from the derived absorption coefficients. The Aeth is installed at AMF1.

\section{2) CAPS PM $\mathrm{EX}$}

The Cavity Attenuated Phase Shift Extinction Monitor $\left(\right.$ CAPS PM $\left._{\mathrm{ex}}\right)$ (Aerodyne Research, Inc.) measures particle optical light extinction, the sum of scattering plus absorption using cavity phase shift spectroscopy [Kebabian et al. 2007; Sedlacek 2016b (ARM instrument handbook)]. Validations with other measurement techniques have been conducted in the laboratory and during field deployments (Massoli et al. 2010; Petzold et al. 2013). A light-emitting diode generates a squarewave light signal that is injected into one end of a sample cell bounded by two high reflectivity mirrors. Scattering and absorption of light by particles result in a distorted waveform that is characterized by a phase shift dependent on the amount of light extinction. The monitor has a detection limit of $\sim 1 \mathrm{M} \mathrm{m}^{-1}(2 \sigma)$ in 1-s integration time. Particle-free background samples are used to subtract gas phase absorption and correct for baseline drift. A single-wavelength $(630 \mathrm{~nm})$ or a three-wavelength $(450,525$, and $630 \mathrm{~nm})$ version of the instrument is de-

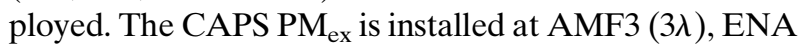
$(1 \lambda)$, and SGP $(3 \lambda)$.

\section{3) NePHELOMETER}

The nephelometer (TSI, Inc.) measures the light scattered by aerosol particles at three wavelengths: 450 , 550, and $700 \mathrm{~nm}$ [Anderson et al. 1996; Anderson and Ogren 1998; Uin 2016b (ARM instrument handbook)]. The instrument is capable of measuring total scattering as well as backscattering only (from $90^{\circ}$ to $170^{\circ}$ ). Light scattered by the carrier gas and instrument walls is automatically measured and subtracted from the total measurement.

Prior to measurement, the nephelometer sample air passes through an impactor that periodically switches between 1- and 10- $\mu \mathrm{m}$ cut-point sizes (see the inlet section above). Several AOSs have two nephelometers installed in series with a drying/humidification system in between (see the humidigraph instrument description below) to measure the change in light scattering due to water loss or uptake by particles. The nephelometer is installed at AMF1 (humidigraph), AMF2, AMF3, ENA (humidigraph), and SGP (humidigraph).

\section{4) PSAP}

The Particle Soot Absorption Photometer (PSAP; Radiance Research) measures the light transmission at three visible wavelengths through a substrate on which aerosol particles are continuously collected [Bond et al. 1999;
Virkkula et al. 2005; Springston and Sedlacek 2007; Anderson et al. 1999; Springston 2016a (ARM instrument handbook)]. Measured wavelengths are nominally 470 , 522, and $660 \mathrm{~nm}$ but vary within $12 \mathrm{~nm}$ and are reported in the metadata for each instrument. Aerosol absorption coefficient $\sigma$ is derived as a function of light transmission at each wavelength, which includes corrections for loading and scattering effects (Virkkula 2010; Ogren 2010; Bond et al. 1999).

The change in light transmission is measured in reference to a blank filter that is exposed to the same ambient (particle free) air as the sample. Use of a reference allows for changes in the light source output and ambient conditions (e.g., temperature and pressure) to be removed. Filters are changed when the transmission $<0.7$. Filter substrates are kept constant as using a different substrate would require new correction factors to be calibrated. The PSAP is installed at AMF1, AMF2, AMF3, ENA, and SGP.

\section{5) PASS}

The Photoacoustic Soot Spectrometer (PASS) (Droplet Measurement Technologies, Inc.) measures light absorption and scattering by aerosol particles in a single chamber at three wavelengths: 405, 532, and $781 \mathrm{~nm}$ (Arnott et al. 1999; Flowers et al. 2010; Lack et al. 2006; Dubey et al. 2013). The instrument consists of an acoustic cavity where laser beams are modulated to match the resonance acoustic frequency of a resonator. Sampled aerosol is illuminated by the laser beams, and as the particles absorb light, the surrounding gas expands creating a sound-source pressure wave at the frequency of the resonator. A microphone measures the produced sound for photoacoustic measurement of light absorption. Light scattering is measured with an integrated nephelometer. The PASS was installed at AMF1 (discontinued).

\section{c. Chemical composition}

\section{1) ACSM}

The Aerosol Chemical Speciation Monitor (ACSM) (Aerodyne Research, Inc.) measures the chemical mass concentration of nonrefractory submicrometer aerosol species: ammonium, chloride, organic, nitrate, sulfate (Jayne et al. 2000; Ng et al. 2011; Watson 2017). Aerosol is directly sampled into the ACSM and focused with an aerodynamic lens (Zhang et al. 2002) into a particle beam under vacuum $50 \%$ transmission range for particles between 75 and $650 \mathrm{~nm}$ (Liu et al. 2007). The particle beam is thermally vaporized at $600^{\circ} \mathrm{C}$ and ionized by electron impact at $70 \mathrm{eV}$, enabling comparison with the NIST electron impact mass spectral database. Quadrupole $Q$ or time-of-flight (ToF) mass spectrometry is used to detect 
chemical composition. Ion signals are summed for each chemical species to determine particulate mass concentrations in micrograms per meter cubed (Allan et al. 2004). The sample is dried with a Nafion dryer. The ACSM is installed at AMF1 $(Q)$, AMF3 (ToF), ENA $(Q)$, and $\operatorname{SGP}(Q)$.

\section{2) PILS}

The Particle-into-Liquid Sampler (PILS) measures bulk chemical composition of aerosol particles (Watson 2016a). PILS consists of three main components: extraction unit (Applikon Analytical B.V.), ion chromatographs (Metrohm), and total organic carbon analyzer (GE Power and Water Process Technologies). The instrument works by growing the particles with water vapor and collecting the resulting liquid on an impact surface. Two different modes allow the analysis of water-soluble aerosol using ion chromatography for inorganic ionic species (cations and anions) or for total organic carbon (TOC). Ionic species detected include $\mathrm{Li}^{+}, \mathrm{Na}^{+}, \mathrm{NH}_{4}^{+}, \mathrm{K}^{+}, \mathrm{Mg}^{++}$, $\mathrm{Ca}^{++}, \mathrm{Cl}^{-}, \mathrm{Br}^{-}, \mathrm{NO}_{3}^{-}, \mathrm{PO}_{4}^{-}, \mathrm{SO}_{4}^{-}$, and oxalate ${ }^{-}$.

Denuders are used to remove gaseous compounds prior to entering the PILS. Particles that activate within the supersaturated growth chamber and grow to $\sim 1-\mu \mathrm{m}$ diameter are collected on a single-orifice impactor, whereupon the liquid sample is removed using a constant flow of purified water with an internal standard. The PILS was installed at MAOS (discontinued).

3) SP2

The Single Particle Soot Photometer (SP2) (Droplet Measurement Technologies, Inc.) provides a particleresolved measurement of refractory black carbon (rBC) [Sedlacek 2017 (ARM instrument handbook)]. The instrument works by injecting individual rBC-containing particles into the cavity of a continuous wave neodymiumdoped yttrium-aluminum-garnet (Nd:YAG) laser where the $\mathrm{rBC}$ component will absorb the 1064-nm radiation until it incandesces. The amplitude of this incandescence signal is proportional to the $\mathrm{rBC}$ mass (Stephens et al. 2003). In addition to a mass concentration $\left(\mathrm{ng} \mathrm{m}^{-3}\right)$, this particle-resolved measurement can be used to derive $\mathrm{rBC}$ size/mass distributions (Schwarz et al. 2006; Moteki and Kondo 2008). Using collocated scattering detectors in the $\mathrm{SP} 2$ allows to probe the $\mathrm{rBC}$ mixing state (Sedlacek et al. 2012, 2015). The SP2 is installed at AMF1.

\section{d. Hygroscopicity}

\section{1) $\mathrm{CCN}$}

The Cloud Condensation Nuclei Counter (CCN) (Droplet Measurement Technologies Inc.) measures the concentration of aerosol particles that can act as cloud condensation nuclei [Rose et al. 2007; Roberts and Nenes 2005; Uin 2016c (ARM instrument handbook)]. The instrument works by drawing the aerosol sample through a column filled with supersaturated water vapor, which condenses on aerosol particles. Particles that take up water and grow above a certain size ("activated" particles) are then optically counted by illuminating them with a laser beam and registering the pulses of scattered light. The level of supersaturation is controlled by changing the temperature gradient inside the column, which enables measuring the activated particle concertation as a function of supersaturation. The supersaturation is changed stepwise, typically from $0 \%$ to $1 \%$.

All but one deployed CCNs are the CCN-200 model with two columns. The second column is kept at a fixed low supersaturation and used as a reference to measure changes in the particle concentration due to changing ambient conditions. The CCN is installed at AMF1, AMF2, AMF3, ENA (CCN-100, single column), and SGP.

\section{2) HT-DMA}

The Humidified Tandem Differential Mobility Analyzer (HT-DMA) (Brechtel Manufacturing, Inc.) measures the change in aerosol particle size (growth factor) due to water uptake, utilizing two DMAs and a humidification system connected in series [Lopez-Yglesias et al. 2014; Uin 2016d (ARM instrument handbook)]. The aerosol sample is dried, and the first DMA is used to select a narrow size range of dry aerosol particles. The selected particles are then exposed to clean particle-free air with high RH in the humidification system, and the second (humidified) DMA, along with a CPC, is used to measure the resulting size distribution of the humidified particles. From the initial dry particle size and the size distribution of the humidified particles, a growth factor is derived. The initial dry size is changed in 50-nm steps from 50 to $250 \mathrm{~nm}$, and a size distribution of humidified particles is recorded at each step.

Newer HT-DMA models are also capable of doing direct ambient particle size measurements between regular humidified measurements using an additional CPC connected to the first DMA. Changes enabling this feature are being implemented on the existing ARM HT-DMAs. The HT-DMA is installed at AMF1, AMF2, AMF3, ENA, and SGP.

\section{3) HumidigrapH}

The "humidigraph" is a custom-built system to measure the change in light scattering by aerosol particles due to water uptake (Pekour et al. 2013). The humidigraph consists of a "dry" nephelometer sampling ambient air, a sample drying/humidification system and a "wet" nephelometer sampling the humidifier output, all connected in 


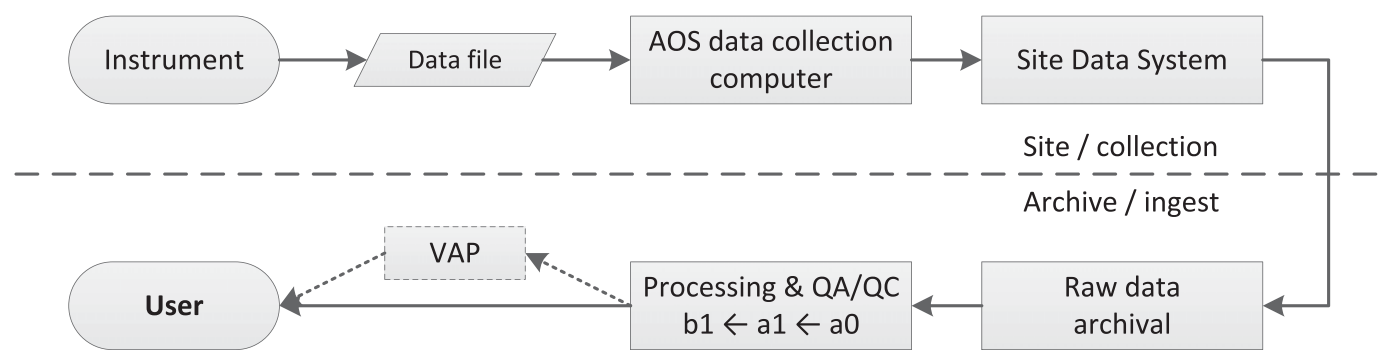

FIG. 5. Flowchart of the AOS data collection and handling process.

series. This configuration is possible because the light scattering measurement in a nephelometer is nondestructive and the sample can be passed on for further conditioning and measurements.

The humidification system is made up of two sets of Nafion cells with actively controlled purge flows. The purge flows are periodically switched between humid and dry air in an opposite way between the two sets of Nafion cells, so that the sample is either first dried and then humidified (deliquescence measurement) or vice versa (efflorescence measurement). The purge flow for the first set of cells is generally kept at a fixed rate while the flow for the second set is slowly increased to scan up or down in the sample $\mathrm{RH}$, depending on the measurement type. The measurement cycle of the humidigraph is synchronized with the AOS impactor switching schedule to provide deliquescence and efflorescence measurements at both impactor cutoff sizes. The humidigraph is installed at AMF1, ENA, and SGP.

\section{e. Trace gases and meteorological measurements}

\section{1) $\mathrm{CO} / \mathrm{H}_{2} \mathrm{O} / \mathrm{N}_{2} \mathrm{O}$ ANALYZER}

$\mathrm{CO} / \mathrm{H}_{2} \mathrm{O} / \mathrm{N}_{2} \mathrm{O}$ analyzer (Los Gatos Research) measures the molar fraction of $\mathrm{CO}, \mathrm{H}_{2} \mathrm{O}$ and $\mathrm{N}_{2} \mathrm{O}$ [Springston 2015 (ARM instrument handbook)]. The instrument works by measuring optical absorbance in the near-infrared using a high-finesse optical cavity $(R \sim 0.9999)$ with an effective pathlength on the order of thousands of meters. A roomtemperature diode laser is scanned over selected absorption features of the three target species. The measured absorption spectra are combined with the measured gas temperature and pressure to determine a quantitative measurement of molar mixing ratios. The $\mathrm{CO} / \mathrm{H}_{2} \mathrm{O} / \mathrm{N}_{2} \mathrm{O}$ analyzer is installed at AMF1, AMF2, AMF3, and ENA.

\section{2) $\mathrm{GHG}\left(\mathrm{CO}_{2}, \mathrm{CH}_{4}, \mathrm{H}_{2} \mathrm{O}\right)$ ANALYZER}

The greenhouse gas (GHG) measurement system is a combination of two systems in series: the tower gas processing (TGP) system, an instrument rack that pulls, pressurizes, and dries airstreams from an atmospheric sampling tower through a series of control and monitoring components, and the Picarro model G2301 cavity ringdown spectrometer, which measures $\mathrm{CO}_{2}, \mathrm{CH}_{4}$, and $\mathrm{H}_{2} \mathrm{O}$ vapor; the primary measurements of the GHG system [Biraud and Reichl 2016 (ARM instrument handbook)]. The TGP is equipped with a cooler and a liquid water detector that will stop pressurized flow from the tower sample line to the Picarro analyzer if liquid water is detected in the sample stream. This prevents liquid water from entering the cell cavity of the Picarro instrument. Prior to entering the Picarro analyzer, the sample stream is further dried by Nafion and Drierite dryers. The GHG analyzer is installed at AMF3, ENA, and SGP (outside the AOS).

\section{3) $\mathrm{O}_{3}$ ANALYZER}

The model 49i $\mathrm{O}_{3}$ analyzer (Thermo Fisher Scientific, Inc.) measures the molar fraction of $\mathrm{O}_{3}$ [Springston 2016b (ARM instrument handbook)]. The instrument works by measuring light absorbance at $254 \mathrm{~nm}$, which is directly related to ozone concentration through the Beer-Lambert law. The dual cell configuration with selective removal of ozone in the reference cell reduces any response from interfering species. Following each four second measurement cycle, the reference and sample cells are reversed to remove optical effects (change in lamp output, detector gain, cell cleanliness, etc.). The instrument inlet has a 5- $\mu \mathrm{m}$ Teflon filter installed to keep the optics clean. The $\mathrm{O}_{3}$ analyzer is installed in AMF1, AMF2, AMF3, and ENA.

\section{4) $\mathrm{NO} / \mathrm{NO}_{2} / \mathrm{NO}_{Y}$ ANALYZER}

A custom three-channel instrument (Air Quality Design) is based on the cores of two model 42i TLE (Thermo Fisher Scientific, Inc.) NO analyzers. The analyzers have had their molybdenum converters and mass flow elements removed to only measure NO. One analyzer alternates between reporting $\mathrm{NO}$ and $\mathrm{NO}+\mathrm{NO}_{2}$ based on the state of a photolytic converter at the inlet. The other analyzer reports total $\mathrm{NO}_{y}\left(\mathrm{NO}+\mathrm{NO}_{2}+\right.$ $\mathrm{HNO}_{3}+\mathrm{RNO}_{3}+$ aerosol $\mathrm{NO}_{3}^{-}$) using a molybdenum converter at the inlet. A custom, converter/inlet box is mounted on a fold-down tower $10 \mathrm{~m}$ above ground level. The temperature-controlled box contains a photolysis 


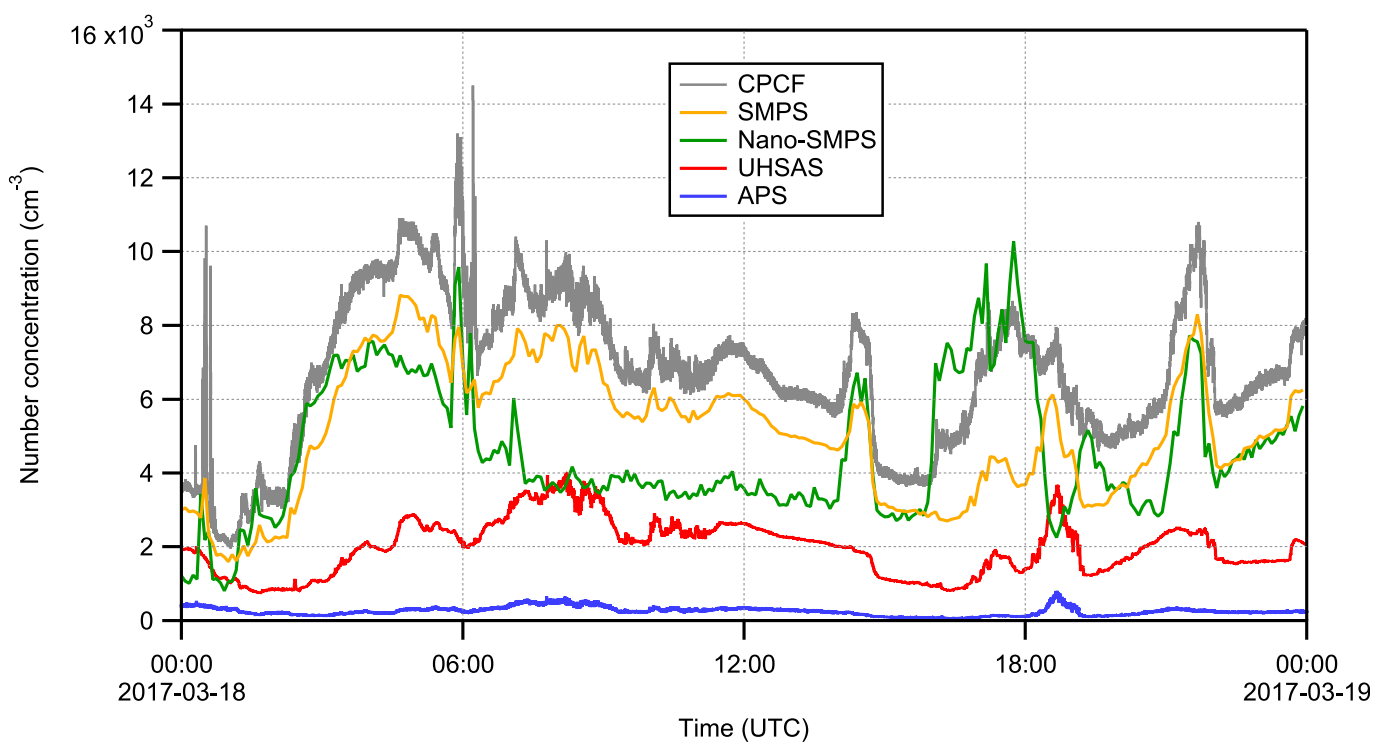

FIG. 6. Time series of total particle number concentrations as measured by several collocated instruments in SGP AOS. Diagnostic plots like these facilitate quick data quality checks by showing how well data from several instruments track and whether differences in magnitude correspond to the different measurement ranges and measurement principles (e.g., mobility vs aerodynamic vs optical sizing) of the individual instruments.

cell with high-intensity LEDs specific for $\mathrm{NO}_{2}$, a molybdenum converter set to $325^{\circ} \mathrm{C}$, and a mass-flow controller for each analyzer. The $\mathrm{NO} / \mathrm{NO}_{2}$ channel is preceded by a $5-\mu \mathrm{m}$ Teflon filter to keep the optics clean. The photolytic converter is switched on and off with a period of $2 \mathrm{~min}$. In the off state, the NO analyzer reports only NO concentration. In the on state, the NO analyzer reports $\mathrm{NO}+\mathrm{CE} \times \mathrm{NO}_{2}$ concentration, where $\mathrm{CE}$ is the conversion efficiency for $\mathrm{NO}_{2}$ to $\mathrm{NO}$. The molybdenum converter is operated continuously. Downstream of the converter a stainless steel sintered metal filter prevents line contamination. The $\mathrm{NO} / \mathrm{NO}_{2} / \mathrm{NO}_{y}$ analyzer was installed at MAOS (discontinued).

\section{5) $\mathrm{SO}_{2}$ ANALYZER}

The model 43i TLE $\mathrm{SO}_{2}$ analyzer (Thermo Fisher Scientific, Inc.) measures the molar fraction of $\mathrm{SO}_{2}$ [Springston 2016c (ARM instrument handbook)]. The instrument works by measuring fluorescence from $\mathrm{SO}_{2}$ in the ultraviolet region. A proprietary hydrocarbon "kicker" removes interfering compounds from the sample stream. The resulting fluorescence is proportional to the molar concentration of $\mathrm{SO}_{2}$ in the sample. The instrument inlet has a 5- $\mu \mathrm{m}$ Teflon filter installed to keep the optics clean. The $\mathrm{SO}_{2}$ analyzer was installed at MAOS (discontinued) and is installed at SGP.

\section{6) PTRMS}

The proton transfer reaction mass spectrometer (PTRMS) (Ionicon) measures mixing ratios of gas-phase species known as volatile organic compounds (VOCs), including isoprene, monoterpenes, acetone, methanol, acetonitrile, benzene, toluene, xylene, and so on using chemical ionization and ToF mass spectrometry [de Gouw and Warneke 2007; Watson 2016b (ARM instrument handbook)]. Chemical ionization is done by the gentle proton transfer reaction of protonated water $\left(\mathrm{H}_{3} \mathrm{O}^{+}\right)$with the sample to limit fragmentation and maximize detection of the original analyte molecule. If the proton affinity of the analyte is greater than water, proton transfer occurs, and a positive ion is detected in the mass spectrometer at the molecular ion's mass-to-charge ratio. VOC mixing ratios are determined from the number of molecular ions detected for each compound relative to the number of air molecules in the reaction chamber. Individual VOCs can be detected down to parts per trillion (by volume) limits for some compounds in high time resolution (seconds) over a range of typically $0-450$ atomic mass units for the parent ion. The PTRMS was installed at MAOS (discontinued).

\section{7) Meteorological Station}

The model WXT520 weather transmitter (Vaisala) measures six meteorological parameters: wind speed and direction, precipitation, atmospheric pressure, temperature, and relative humidity [Kyrouac 2016 (ARM instrument handbook)]. The precipitation and wind-sensing elements are heated in icing conditions. All parameters are recorded at $1 \mathrm{~Hz}$. The wind direction 


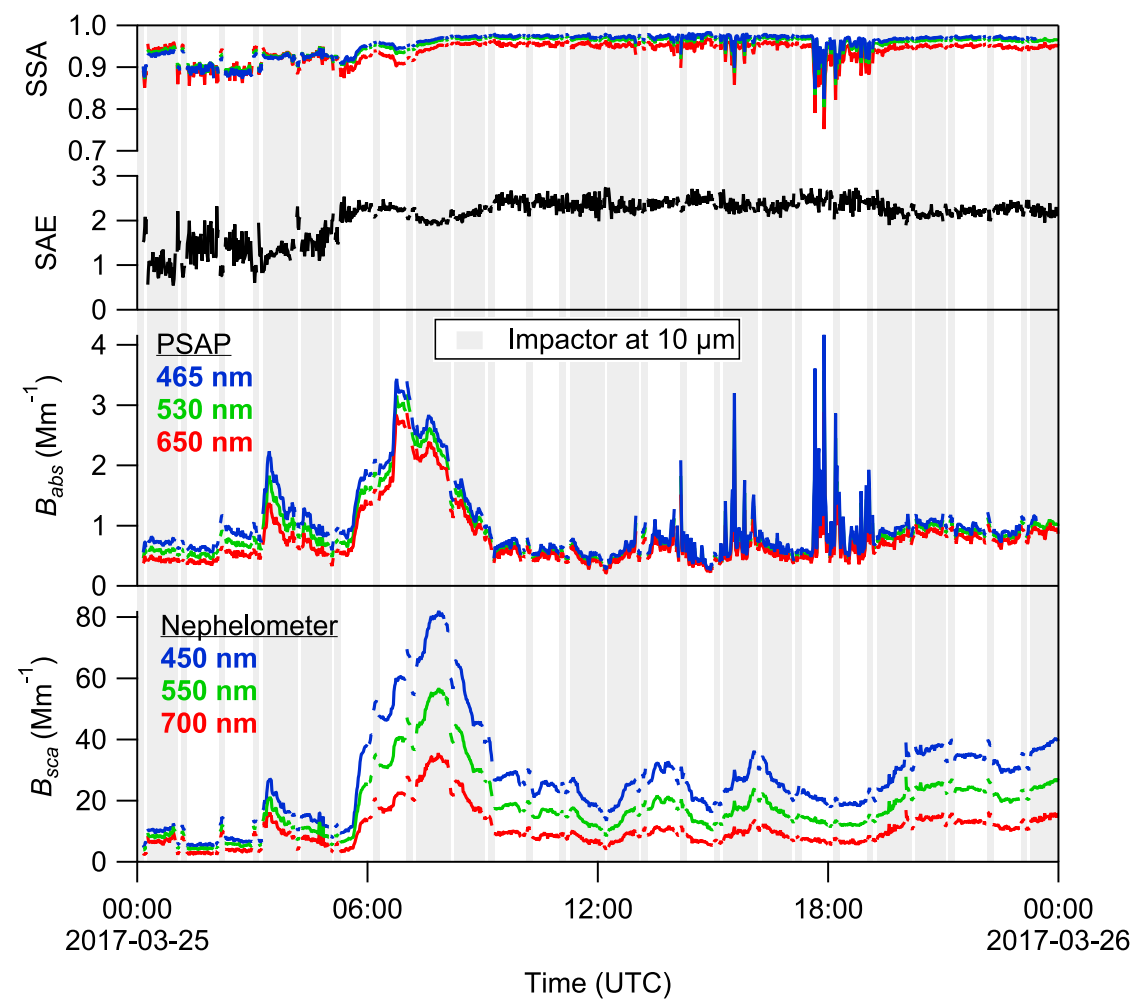

FIG. 7. Time series of aerosol optical scattering and absorption coefficients along with the higher-order AOP AE and SSA data products from the SGP AOS spanning across the visible wavelength region. Scattering and absorption coefficients are reported at the nominal wavelengths measured by the respective instruments. The AE is presented for the 450- and 700 -nm nephelometer data as the difference across all wavelengths is within $7 \%$ on average for this time period, whereas the SSA is presented at all three PSAP wavelengths. Data at $10-\mu \mathrm{m}$ impactor cut size are highlighted with a gray background.

sensor is oriented to magnetic north, except for shipboard deployments, where it is oriented to the bow of the ship. The meteorological station was installed at AMF1, AMF2, AMF3, ENA, and SGP.

\section{Data processing and end user products}

Raw data collected by SDSs are periodically transferred to the ARM Data Archive for storage and higherlevel processing (Fig. 5) (McCord and Voyles 2016). The raw data are compressed and archived in an unedited form as primary data, permanently available for reprocessing should algorithms change.

Data processing begins with ingest-extraction of data from the raw data files following the logic defined for each file, and storage in a common format. Not all data from the raw data files are ingested, as diagnostic and auxiliary data not immediately useful for the end user are typically omitted. The ingested data are automatically quality checked based on criteria defined by the instrument mentors. This can range from checking for valid variable values and instrument status flags to checking for covariance of several variables, possibly from different collocated instruments. Analysts from the ARM Data Quality office manually review all the processed data and will give extra scrutiny to periods that are flagged by these automatic quality checks.

To facilitate the manual QA/QC, a series of diagnostic plots are automatically generated from the ingested data, displaying key variables or variable ratios from one or more collocated instruments (Fig. 6). These plots help the ARM Data Quality Office and the instrument mentors to track and troubleshoot any data quality issue, but are also publicly visible to the users for monitoring the conditions during a field campaign. If an issue is confirmed, a "data quality problem report" (DQPR) is entered into a database, so that its resolution can be tracked (Peppler et al. 2016, 2008). Once the issue has been resolved, a "data quality report" (DQR) is filed, specifying the time range for the issue and describing how (if at all) it affected the data and whether any corrections or workarounds are needed. The DQRs are automatically linked to the data 


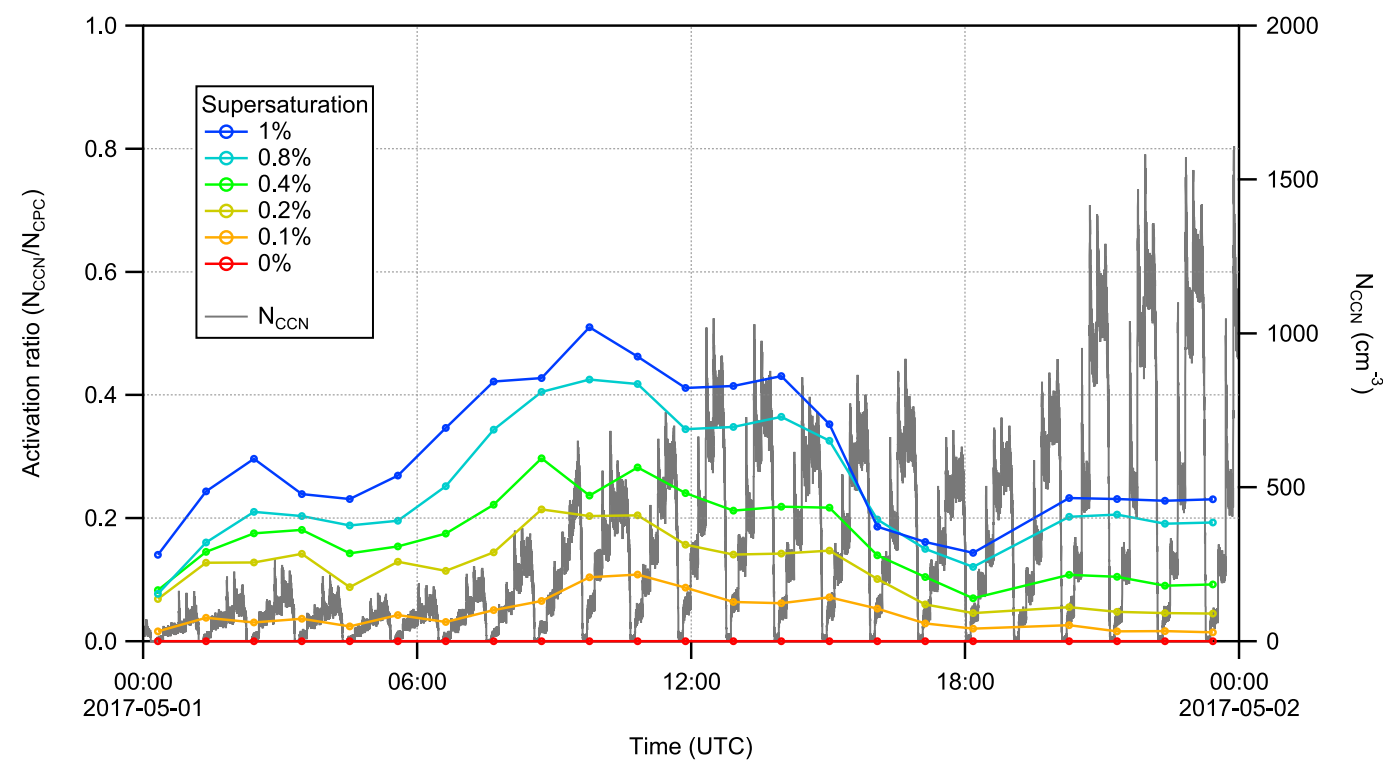

FIG. 8. Time series of activated cloud droplet number concentration data from the CCN instrument $\left(N_{\mathrm{CCN}}\right)$ in SGP AOS and ARM-calculated higher-level CCN spectra (particle activation ratio) as a function of supersaturation. Activation ratio is based on the data from collocated $\mathrm{CPC}$ and $\mathrm{CCN}$ instruments.

and are visible to the users when browsing and downloading data online through the ARM Data Discovery service (accessible through the main ARM website).

Ingested and quality checked data are labeled as a1 level. For most instruments the a1-level data are further processed into b1 level by applying instrument calibration data supplied by instrument mentors and correction factors defined in the literature or by the manufacturer. Additionally, derived quantities that are not directly measured by an instrument or are based on the outputs of several collocated instruments are produced as "value added products" (VAPs; c1-level data), curated by ARM's particle total number translators.

As an example of higher-level data available for the AOS aerosol optical property measurements, Fig. 7 shows data from the aerosol optical properties (AOP) VAP. The AOP VAP includes data from collocated PSAP and nephelometer instruments to determine aerosol extinction, Ångström exponents (AEs), and single scattering albedo (SSA). The data are averaged to 1 min time stamps (Springston and Sedlacek 2007) and corrections are applied to the data. Light scattering data are corrected for truncation error (Anderson and Ogren 1998) while the absorption data are corrected for filter loading and scattering effects (Bond et al. 1999; Ogren 2010) as well as truncation errors (Virkkula 2010). Similarly to the AOP VAP, ARM provides a higher-level data product for the $\mathrm{CCN}$ instrument-the AOSCCNAVG VAP (Fig. 8). Averaged and filtered $\mathrm{CCN}$ data are extrapolated to yield activated particle concentrations as a function of supersaturation [derived from CCN column temperatures according to Lance et al. (2006)] and combined with concentration data from a collocated CPC to calculate the particle activation ratio for each supersaturation set point.

All levels of processed data are archived and freely available online via the ARM website where they can be browsed and ordered for download. Access to raw data is also possible through a special request. The data can be downloaded as NetCDF or plain ASCII files (1D data only) that include metadata about the instrument, measurement location and the campaign/deployment. To help the users better understand the measurement data, each instrument has an instrument handbook available for download on the ARM website that describes in detail the instrument operation, data format and calibration procedures.

\section{Outlook}

In operating the five new-generation AOSs, ARM strives to provide comprehensive research-grade aerosol measurements. This goal is facilitated by the robust design of the AOSs, which allows consistent operation across a wide range of deployment environments. Instrument complement and operating modes of the AOSs are evolving and are based on the best practices and specific user needs, identified through measurement proposals to ARM or by recommendations from the ARM Aerosol Measurement Science Group (AMSG) 
(McComiskey and Sisterson 2018), which works with the scientific community. Feedback from the community helps to ensure that advanced, well-characterized measurements are made and relevant data products for improving climate science and model forecasts are available to the users. ARM is a scientific user facility and data collected from the ARM AOSs are a researchcommunity resource that are freely shared across government agencies, universities, private companies, international institutions, and individual researchers.

Acknowledgments. The authors thank Anne Jefferson, John Ogren, and Patrick Sheridan for collaborative discussions on instrumentation, inlets, and the general AOS design. The authors also thank Douglas Sisterson for much of the historical perspective and James Mather and Adam Theisen for help in preparing this paper. This paper has been authored by employees of Brookhaven Science Associates, LLC, under Contract DE-SC0012704 with the U.S. Department of Energy. The publisher by accepting the paper for publication acknowledges that the U.S. government retains a nonexclusive, paid-up, irrevocable, worldwide license to publish or reproduce the published form of this paper, or allow others to do so, for U.S. government purposes.

\section{APPENDIX}

\section{Acronyms and Abbreviations}

$\begin{array}{ll}\text { AMF } & \text { ARM Mobile Facility } \\ \text { AMSG } & \text { Aerosol Measurement Science Group } \\ \text { AOS } & \text { Aerosol Observing System } \\ \text { ARM } & \text { Atmospheric Radiation Measurement } \\ \text { BNL } & \text { Brookhaven National Laboratory } \\ \text { DMF } & \text { Data Management Facility } \\ \text { DOE } & \text { U.S. Department of Energy } \\ \text { DQPR } & \text { Data quality problem report } \\ \text { DQR } & \text { Data quality report } \\ \text { ENA } & \text { Eastern North Atlantic } \\ \text { IOP } & \text { Aerosol Intensive Operational Period } \\ \text { OLI } & \text { Oliktok Point } \\ \text { PI } & \text { Principal investigator } \\ \text { MAOS } & \text { Mobile Aerosol Observing System } \\ \text { SDS } & \text { Site data system } \\ \text { SGP } & \text { Southern Great Plains } \\ \text { VAP } & \text { Value added product } \\ \text { VI } & \text { Virtual instrument }\end{array}$

\section{REFERENCES}

Allan, J. D., and Coauthors, 2004: A generalised method for the extraction of chemically resolved mass spectra from Aerodyne aerosol mass spectrometer data. J. Aerosol Sci., 35, 909-922, https://doi.org/10.1016/j.jaerosci.2004.02.007.

Anderson, T. L., and J. A. Ogren, 1998: Determining aerosol radiative properties using the TSI 3563 integrating nephelometer. Aerosol Sci. Technol., 29, 57-69, https://doi.org/10.1080/ 02786829808965551.

— sensitivity, three-wavelength, total scatter/backscatter nephelometer. J. Atmos. Oceanic Technol., 13, 967-986, https://doi.org/ 10.1175/1520-0426(1996)013<0967:PCOAHS > 2.0.CO;2.

, D. S. Covert, J. D. Wheeler, J. M. Harris, K. D. Perry, B. E. Trost, D. J. Jaffe, and J. A. Ogren, 1999: Aerosol backscatter fraction and single scattering albedo: Measured values and uncertainties at a coastal station in the Pacific Northwest. J. Geophys. Res., 104, 26 793-26807, https://doi.org/10.1029/ 1999JD900172.

ARM, 2016: Atmospheric Radiation Measurement (ARM) Climate Research Facility management plan. ARM Rep. DOE/SC-ARM-13-022, 27 pp.

Arnott, W. P., H. Moosmüller, C. F. Rogers, T. Jin, and R. Bruch, 1999: Photoacoustic spectrometer for measuring light absorption by aerosol: Instrument description. Atmos. Environ., 33, 2845-2852, https://doi.org/10.1016/S1352-2310(98)00361-6.

- K. Hamasha, H. Moosmüller, P. J. Sheridan, and J. A. Ogren, 2005: Towards aerosol light-absorption measurements with a 7-wavelength aethalometer: Evaluation with a photoacoustic instrument and 3-wavelength nephelometer. Aerosol Sci. Technol., 39, 17-29, https://doi.org/10.1080/027868290901972.

Biraud, S. C., and K. Reichl, 2016: Aerosol Observing System greenhouse gas (AOS GHG) handbook. ARM Tech. Rep. DOE/SC-ARM-TR-175, 36 pp., https://doi.org/10.2172/1246161.

Bond, T. C., T. L. Anderson, and D. Campbell, 1999: Calibration and intercomparison of filter-based measurements of visible light absorption by aerosols. Aerosol Sci. Technol., 30, 582600, https://doi.org/10.1080/027868299304435.

Bullard, R. L., J. Uin, S. R. Springston, C. Kuang, and S. Smith, 2017: Aerosol Inlet Characterization Experiment report. ARM Tech. Rep. DOE/SC-ARM-TR-191, 19 pp., https:// doi.org/10.2172/1355300.

Cai, Y., D. C. Montague, W. Mooiweer-Bryan, and T. Deshler, 2008: Performance characteristics of the ultra high sensitivity aerosol spectrometer for particles between 55 and $800 \mathrm{~nm}$ : Laboratory and field studies. J. Aerosol Sci., 39, 759-769, https://doi.org/10.1016/j.jaerosci.2008.04.007.

Carrico, C. M., M. J. Rood, and J. A. Ogren, 1998: Aerosol light scattering properties at Cape Grim, Tasmania, during the First Aerosol Characterization Experiment (ACE 1). J. Geophys. Res., 103, 16565-16 574, https://doi.org/10.1029/98JD00685.

Charlson, R. J., S. E. Schwartz, J. M. Hales, R. D. Cess, J. A. Coakley, J. E. Hansen, and D. J. Hofmann, 1992: Climate forcing by anthropogenic aerosols. Science, 255, 423-430, https://doi.org/10.1126/science.255.5043.423.

Cress, T. S., D. L. Sisterson, T. S. Cress, and D. L. Sisterson, 2016: Deploying the ARM sites and supporting infrastructure. The Atmospheric Radiation Measurement (ARM) Program: The First 20 Years, Meteor. Monogr., No. 57, Amer. Meteor. Soc., https://doi.org/10.1175/AMSMONOGRAPHS-D-15-0049.1.

de Gouw, J., and C. Warneke, 2007: Measurements of volatile organic compounds in the Earth's atmosphere using protontransfer-reaction mass spectrometry. Mass Spectrom. Rev., 26, 223-257, https://doi.org/10.1002/mas.20119.

Drinovec, L., and Coauthors, 2015: The "dual-spot" aethalometer: An improved measurement of aerosol black carbon with real-time 
loading compensation. Atmos. Meas. Tech., 8, 1965-1979, https:// doi.org/10.5194/amt-8-1965-2015.

Dubey, M., S. Springston, A. Koontz, and A. Aiken, 2013: Photoacoustic Soot Spectrometer (PASS) instrument handbook. ARM Tech. Rep. DOE/SC-ARM-TR-123, 55 pp., https:// doi.org/10.2172/1226795.

Ferrare, R., G. Feingold, S. Ghan, J. Ogren, B. Schmid, S. E. Schwartz, and P. Sheridan, 2006: Preface to special section Atmospheric Radiation Measurement Program May 2003 intensive operations period examining aerosol properties and radiative influences. J. Geophys. Res., 111, D05S01, https:// doi.org/10.1029/2005JD006908.

Flowers, B. A., M. K. Dubey, C. Mazzoleni, E. A. Stone, J. J. Schauer, S. W. Kim, and S. C. Yoon, 2010: Optical-chemical-microphysical relationships and closure studies for mixed carbonaceous aerosols observed at Jeju Island; 3-laser photoacoustic spectrometer, particle sizing, and filter analysis. Atmos. Chem. Phys., 10, 10 387-10 398, https://doi.org/10.5194/acp-10-10387-2010.

Hansen, A. D. A., H. Rosen, and T. Novakov, 1984: The aethalometer-An instrument for the real-time measurement of optical absorption by aerosol particles. Sci. Total Environ., 36, 191-196, https://doi.org/10.1016/0048-9697(84)90265-1.

Hermann, M., B. Wehner, O. Bischof, H.-S. Han, T. Krinke, W. Liu, A. Zerrath, and A. Wiedensohler, 2007: Particle counting efficiencies of new TSI condensation particle counters. J. Aerosol Sci., 38, 674-682, https://doi.org/10.1016/j.jaerosci.2007.05.001.

IPCC, 2014: Climate Change 2013: The Physical Science Basis. Cambridge University Press, 1535 pp., https://doi.org/10.1017/ CBO9781107415324.

Jayne, J. T., D. C. Leard, X. F. Zhang, P. Davidovits, K. A. Smith, C. E. Kolb, and D. R. Worsnop, 2000: Development of an aerosol mass spectrometer for size and composition analysis of submicron particles. Aerosol Sci. Technol., 33, 49-70, https:// doi.org/10.1080/027868200410840.

Kebabian, P. L., W. A. Robinson, and A. Freedman, 2007: Optical extinction monitor using cw cavity enhanced detection. Rev. Sci. Instrum., 78, 063102, https://doi.org/10.1063/1.2744223.

Knutson, E. O., and K. T. Whitby, 1975: Aerosol classification by electric mobility: Apparatus, theory, and applications. J. Aerosol Sci., 6, 443-451, https://doi.org/10.1016/00218502(75)90060-9.

Kuang, C., 2016a: Condensation particle counter (CPC) instrument handbook. ARM Tech. Rep. DOE/SC-ARM-TR-145, 22 pp., https://doi.org/10.2172/1245983.

_, 2016b: TSI Model 3936 scanning mobility particle spectrometer instrument handbook. ARM Tech. Rep. DOE/SCARM-TR-147, 22 pp., https://doi.org/10.2172/1245993.

Kyrouac, J., 2016: Aerosol Observing System Surface Meteorology instrument handbook. ARM Tech. Rep. DOE/SC-ARM-TR184, 15 pp., https://doi.org/10.2172/1251423.

Lack, D. A., E. R. Lovejoy, T. Baynard, A. Pettersson, and A. R Ravishankara, 2006: Aerosol absorption measurement using photoacoustic spectroscopy: Sensitivity, calibration, and uncertainty developments. Aerosol Sci. Technol., 40, 697-708, https://doi.org/10.1080/02786820600803917.

Lance, S., A. Nenes, J. Medina, and J. N. Smith, 2006: Mapping the operation of the DMT continuous flow CCN counter. Aerosol Sci. Technol., 40, 242-254, https://doi.org/10.1080/ 02786820500543290

Leifer, R., R. H. Knuth, and H. N. Lee, 1994: Surface aerosol measurements at Lamont, Oklahoma. Proc. Third Atmospheric Radiation Measurement Science Team Meeting, Washington, DC, U.S. Department of Energy, 349-351.
Liu, B. Y., and D. Y. Pui, 1974: A submicron aerosol standard and the primary, absolute calibration of the condensation nuclei counter. J. Colloid Interface Sci., 47, 155-171, https://doi.org/ 10.1016/0021-9797(74)90090-3.

Liu, P. S. K., and Coauthors, 2007: Transmission efficiency of an aerodynamic focusing lens system: Comparison of model calculations and laboratory measurements for the Aerodyne aerosol mass spectrometer. Aerosol Sci. Technol., 41, 721-733, https://doi.org/10.1080/02786820701422278.

Lopez-Yglesias, X. F., M. C. Yeung, S. E. Dey, F. J. Brechtel, and C. K. Chan, 2014: Performance Evaluation of the Brechtel Mfg. Humidified Tandem Differential Mobility Analyzer (BMI HTDMA) for studying hygroscopic properties of aerosol particles. Aerosol Sci. Technol., 48, 969-980, https://doi.org/ 10.1080/02786826.2014.952366.

Massoli, P., P. L. Kebabian, T. B. Onasch, F. B. Hills, and A. Freedman, 2010: Aerosol light extinction measurements by cavity attenuated phase shift (CAPS) spectroscopy: Laboratory validation and field deployment of a compact aerosol particle extinction monitor. Aerosol Sci. Technol., 44, 428-435, https://doi.org/10.1080/02786821003716599.

Mather, J. H., and J. W. Voyles, 2013: The ARM Climate Research Facility: A review of structure and capabilities. Bull. Amer. Meteor. Soc., 94, 377-392, https://doi.org/10.1175/BAMS-D11-00218.1.

McComiskey, A., and R. A. Ferrare, 2016: Aerosol physical and optical properties and processes in the ARM Program. The Atmospheric Radiation Measurement (ARM) Program: The First 20 Years, Meteor. Monogr., No. 57, Amer. Meteor. Soc., https://doi.org/10.1175/AMSMONOGRAPHS-D-15-0028.1.

, and D. Sisterson, 2018: ARM Aerosol Measurement Science Group Strategic Planning Workshop 2017. ARM Tech. Rep. DOE/SC-ARM-TR-207, 49 pp.

McCord, R., and J. Voyles, 2016: The ARM data system and archive. The Atmospheric Radiation Measurement (ARM) Program: The First 20 Years, Meteor. Monogr., No. 57, Amer. Meteor. Soc., https://doi.org/10.1175/AMSMONOGRAPHS-D-15-0043.1.

Miller, M. A., K. Nitschke, T. P. Ackerman, W. R. Ferrell, N. Hickmon, and M. Ivey, 2016: The ARM mobile facilities. The Atmospheric Radiation Measurement (ARM) Program: The First 20 Years, Meteor. Monogr., No. 57, Amer. Meteor. Soc., https://doi.org/10.1175/AMSMONOGRAPHS-D-15-0051.1.

Moteki, N., and Y. Kondo, 2008: Method to measure timedependent scattering cross sections of particles evaporating in a laser beam. J. Aerosol Sci., 39, 348-364, https://doi.org/ 10.1016/j.jaerosci.2007.12.002.

Myhre, G., and Coauthors, 2009: Modelled radiative forcing of the direct aerosol effect with multi-observation evaluation. Atmos. Chem. Phys., 9, 1365-1392, https://doi.org/10.5194/acp-9-1365-2009.

Ng, N. L., and Coauthors, 2011: An aerosol chemical speciation monitor (ACSM) for routine monitoring of the composition and mass concentrations of ambient aerosol. Aerosol Sci. Technol., 45, 780-794, https://doi.org/10.1080/02786826.2011.560211.

Ogren, J. A., 2010: Comment on "Calibration and intercomparison of filter-based measurements of visible light absorption by aerosols."' Aerosol Sci. Technol., 44, 589-591, https://doi.org/ 10.1080/02786826.2010.482111.

Pekour, M. S., B. Schmid, D. Chand, J. M. Hubbe, C. D. Kluzek, D. A. Nelson, J. M. Tomlinson, and D. J. Cziczo, 2013: Development of a new airborne humidigraph system. Aerosol Sci. Technol., 47, 201-207, https://doi.org/10.1080/02786826.2012.741274.

Penner, J. E., R. E. Dickinson, and C. A. O'Neill, 1992: Effects of aerosol from biomass burning on the global radiation budget. 
Science, 256, 1432-1434, https://doi.org/10.1126/science.256. 5062.1432.

Peppler, R., and Coauthors, 2008: Quality assurance of ARM Program Climate Research Facility data. ARM Tech. Rep. DOE/SC-ARM/TR-082, 71 pp., https://doi.org/10.2172/948030.

—, K. E. Kehoe, J. W. Monroe, A. K. Theisen, and S. T. Moore, 2016: The ARM Data Quality Program. The Atmospheric Radiation Measurement (ARM) Program: The First 20 Years, Meteor. Monogr., No. 57, Amer. Meteor. Soc., https://doi.org/ 10.1175/AMSMONOGRAPHS-D-15-0039.1.

Peters, T. M., and D. Leith, 2003: Concentration measurement and counting efficiency of the aerodynamic particle sizer 3321. J. Aerosol Sci., 34, 627-634, https://doi.org/10.1016/S00218502(03)00030-2.

Petzold, A., T. Onasch, P. Kebabian, and A. Freedman, 2013: Intercomparison of a cavity attenuated phase shift-based extinction monitor (CAPS PMex) with an integrating nephelometer and a filter-based absorption monitor. Atmos. Meas. Tech., 6, 1141-1151, https://doi.org/10.5194/ amt-6-1141-2013.

Roberts, G. C., and A. Nenes, 2005: A continuous-flow streamwise thermal-gradient $\mathrm{CCN}$ chamber for atmospheric measurements. Aerosol Sci. Technol., 39, 206-221, https://doi.org/ 10.1080/027868290913988.

Rose, D., G. P. Frank, U. Dusek, S. S. Gunthe, M. O. Andreae, and U. Pöschl, 2007: Calibration and measurement uncertainties of a continuous-flow cloud condensation nuclei counter (DMT$\mathrm{CCNC}$ ): $\mathrm{CCN}$ activation of ammonium sulfate and sodium chloride aerosol particles in theory and experiment. Atmos. Chem. Phys., 8, 1153-1179, https://doi.org/10.5194/acp-8-1153-2008.

Rosen, H., A. D. A. Hansen, R. L. Dod, and T. Novakov, 1980: Soot in urban atmospheres: Determination by an optical absorption technique. Science, 208, 741-744, https://doi.org/ 10.1126/science.208.4445.741.

Schmid, B., R. G. Ellingson, G. M. McFarquhar, B. Schmid, R. G. Ellingson, and G. M. McFarquhar, 2016: ARM aircraft measurements. The Atmospheric Radiation Measurement (ARM) Program: The First 20 Years, Meteor. Monogr., No. 57, Amer. Meteor. Soc., https://doi.org/10.1175/AMSMONOGRAPHSD-15-0042.1.

Schwarz, J. P., and Coauthors, 2006: Single-particle measurements of midlatitude black carbon and light-scattering aerosols from the boundary layer to the lower stratosphere. J. Geophys. Res., 111, D16207, https://doi.org/10.1029/2006JD007076.

Sedlacek, A. J., 2016a: Aethalometer instrument handbook. ARM Tech. Rep. DOE/SC-ARM-TR-156, 36 pp., https://doi.org/ 10.2172/1251391.

— 2016b: Cavity attenuated phase shift (CAPS) monitor instrument handbook. ARM Tech. Rep. DOE/SC-ARM-TR155, 23 pp., https://doi.org/10.2172/1251390.

—_, 2017: Single-Particle Soot Photometer (SP2) instrument handbook. ARM Tech. Rep. DOE/SC-ARM-TR-169, 24 pp., https://doi.org/10.2172/1344179.

—, E. R. Lewis, L. Kleinman, J. Z. Xu, and Q. Zhang, 2012: Determination of and evidence for non-core-shell structure of particles containing black carbon using the Single-Particle Soot Photometer (SP2). Geophys. Res. Lett., 39, L06802, https://doi.org/10.1029/2012GL050905.

$\longrightarrow,-$ T. B. Onasch, A. T. Lambe, and P. Davidovits, 2015: Investigation of refractory black carbon-containing particle morphologies using the Single-Particle Soot Photometer (SP2). Aerosol Sci. Technol., 49, 872-885, https://doi.org/ 10.1080/02786826.2015.1074978.
Sheridan, P. J., D. J. Delene, and J. A. Ogren, 2001: Four years of continuous surface aerosol measurements from the Department of Energy's Atmospheric Radiation Measurement Program Southern Great Plains Cloud and Radiation Testbed site. J. Geophys. Res., 106, 20 735-20 747, https://doi.org/10.1029/ 2001JD000785.

Sisterson, D. L., R. A. Peppler, T. S. Cress, P. J. Lambe, and D. D. Turner, 2016: The ARM Southern Great Plains (SGP) site. The Atmospheric Radiation Measurement (ARM) Program: The First 20 Years, Geophys. Monogr., No. 57, Amer. Meteor. Soc., https:// doi.org/10.1175/AMSMONOGRAPHS-D-16-0004.1.

Springston, S. R., 2015: Carbon monoxide analyzer (COANALYZER) instrument handbook. ARM Tech. Rep. DOE/ SC-ARM-TR-159, 30 pp., https://doi.org/10.2172/1495422.

_ 2016a: Radiance Research Particle Soot Absorption Photometer instrument handbook. ARM Tech. Rep. DOE/SCARM-TR-176, 28 pp., https://doi.org/10.2172/1246162.

- 2016b: Thermo Scientific ozone analyzer instrument handbook. ARM Tech. Rep. DOE/SC-ARM-TR-179, 28 pp., https://doi.org/10.2172/1246164.

- 2016c: Thermo Scientific sulfur dioxide analyzer instrument handbook. ARM Tech. Rep. DOE/SC-ARM-TR-180, 30 pp., https://doi.org/10.2172/1246165.

_ , and A. J. Sedlacek, 2007: Noise characteristics of an instrumental particle absorbance technique. Aerosol Sci. Technol., 41, 1110-1116, https://doi.org/10.1080/02786820701777457.

Stephens, M., N. Turner, and J. Sandberg, 2003: Particle identification by laser-induced incandescence in a solid-state laser cavity. Appl. Opt., 42, 3726-3736, https://doi.org/10.1364/ AO.42.003726.

Stokes, G. M., and S. E. Schwartz, 1994: The Atmospheric Radiation Measurement (ARM) Program: Programmatic background and design of the Cloud and Radiation Test Bed. Bull. Amer. Meteor. Soc., 75, 1201-1221, https://doi.org/10.1175/ 1520-0477(1994)075<1201:TARMPP > 2.0.CO;2.

Stolzenburg, M. R., and P. H. McMurry, 1991: An ultrafine aerosol condensation nucleus counter. Aerosol Sci. Technol., 14, 4865, https://doi.org/10.1080/02786829108959470.

Tigges, L., A. Wiedensohler, K. Weinhold, J. Gandhi, and H. J. Schmid, 2015: Bipolar charge distribution of a soft X-ray diffusion charger. J. Aerosol Sci., 90, 77-86, https://doi.org/ 10.1016/j.jaerosci.2015.07.002.

Turner, D. D., and R. G. Ellingson, 2016: Introduction. The Atmospheric Radiation Measurement (ARM) Program: The First 20 Years, Meteor. Monogr., No. 57, Amer. Meteor. Soc., https://doi.org/10.1175/AMSMONOGRAPHSD-16-0001.1.

Uin, J., 2016a: Ultra-High Sensitivity Aerosol Spectrometer (UHSAS) instrument handbook. ARM Tech. Rep. DOE/SCARM-TR-163, 17 pp., https://doi.org/10.2172/1251410.

- 2016b: Integrating nephelometer instrument handbook. ARM Tech. Rep. DOE/SC-ARM-TR-165, 16 pp., https:// doi.org/10.2172/1246075.

- , 2016c: Cloud condensation nuclei particle counter $(\mathrm{CCN})$ instrument handbook. ARM Tech. Rep. DOE/SC-ARM-TR168, 16 pp., https://doi.org/10.2172/1251411.

_ 2016d: Humidified Tandem Differential Mobility Analyzer instrument handbook. ARM Tech. Rep. DOE/SC-ARM-TR161, 17 pp., https://doi.org/10.2172/1251403.

Virkkula, A., 2010: Correction of the calibration of the 3-wavelength Particle Soot Absorption Photometer (3i PSAP). Aerosol Sci. Technol., 44, 706-712, https://doi.org/10.1080/02786826. 2010.482110 
- N. C. Ahlquist, D. S. Covert, W. P. Arnott, P. J. Sheridan, P. K. Quinn, and D. J. Coffman, 2005: Modification, calibration and a field test of an instrument for measuring light absorption by particles. Aerosol Sci. Technol., 39, 68-83, https:// doi.org/10.1080/027868290901963.

Wang, S. C., and R. C. Flagan, 1990: Scanning electrical mobility spectrometer. Aerosol Sci. Technol., 13, 230-240, https:// doi.org/10.1080/02786829008959441.

Watson, T. B., 2016a: Particle-into-Liquid Sampler (PILS) instrument handbook. ARM Tech. Rep. DOE/SC-ARM-TR162, 20 pp., https://doi.org/10.2172/1251405.
- 2016b: Proton transfer time-of-flight mass spectrometer. $U$ ARM Tech. Rep. DOE/SC-ARM-TR-160, 32 pp., https:// doi.org/10.2172/1251396.

, 2017: Aerosol chemical speciation monitor (ACSM) instrument handbook. ARM Tech. Rep. DOE/SC-ARM-TR196, 21 pp., https://doi.org/10.2172/1375336.

Zhang, X., K. A. Smith, D. R. Worsnop, J. Jimenez, J. T. Jayne, and C. E. Kolb, 2002: A numerical characterization of particle beam collimation by an aerodynamic lens-nozzle system: Part I. An individual lens or nozzle. Aerosol Sci. Technol., 36, 617631, https://doi.org/10.1080/02786820252883856. 